\title{
Prediction of Heavy Metal Removal by Different Liner Materials from Landfill Leachate: Modeling of Experimental Results Using Artificial Intelligence Technique
}

\author{
Nurdan Gamze Turan, ${ }^{1}$ Emine Beril Gümüşsel, ${ }^{1}$ and Okan Ozgonenel ${ }^{2}$ \\ ${ }^{1}$ Department of Environmental Engineering, Engineering Faculty, Ondokuz Mays University, Kurupelit, 55139 Samsun, Turkey \\ ${ }^{2}$ Department of Electric and Electronic Engineering, Engineering Faculty, Ondokuz Mays University, Kurupelit, 55139 Samsun, Turkey \\ Correspondence should be addressed to Okan Ozgonenel; okanoz@omu.edu.tr
}

Received 3 April 2013; Accepted 23 May 2013

Academic Editors: G. Brunetti, I. Ortiz, and C. K. Yoo

Copyright (C) 2013 Nurdan Gamze Turan et al. This is an open access article distributed under the Creative Commons Attribution License, which permits unrestricted use, distribution, and reproduction in any medium, provided the original work is properly cited.

\begin{abstract}
An intensive study has been made to see the performance of the different liner materials with bentonite on the removal efficiency of $\mathrm{Cu}(\mathrm{II})$ and $\mathrm{Zn}$ (II) from industrial leachate. An artificial neural network (ANN) was used to display the significant levels of the analyzed liner materials on the removal efficiency. The statistical analysis proves that the effect of natural zeolite was significant by a cubic spline model with a $99.93 \%$ removal efficiency. Optimization of liner materials was achieved by minimizing bentonite mixtures, which were costly, and maximizing $\mathrm{Cu}(\mathrm{II})$ and $\mathrm{Zn}$ (II) removal efficiency. The removal efficiencies were calculated as $45.07 \%$ and $48.19 \%$ for $\mathrm{Cu}(\mathrm{II})$ and $\mathrm{Zn}(\mathrm{II})$, respectively, when only bentonite was used as liner material. However, $60 \%$ of natural zeolite with $40 \%$ of bentonite combination was found to be the best for $\mathrm{Cu}(\mathrm{II})$ removal (95\%), and $80 \%$ of vermiculite and pumice with $20 \%$ of bentonite combination was found to be the best for $\mathrm{Zn}(\mathrm{II})$ removal (61.24\% and $65.09 \%)$. Similarly, $60 \%$ of natural zeolite with $40 \%$ of bentonite combination was found to be the best for $\mathrm{Zn}$ (II) removal (89.19\%), and $80 \%$ of vermiculite and pumice with $20 \%$ of bentonite combination was found to be the best for $\mathrm{Zn}$ (II) removal (82.76\% and $74.89 \%$ ).
\end{abstract}

\section{Introduction}

Industrial wastes are generated in large amounts in several industries. Because of their toxicity and nonbiodegradable nature, heavy metals are of special significance $[1,2]$. Industrial waste containing heavy metals is being released into the nonengineered open dumps causing detrimental effects not only on humans but also upon environment; therefore it has become imperative to develop methods for treating such wastes [3].

The sanitary landfill method for the ultimate disposal of industrial waste continues to be widely accepted and used due to its economic advantages $[4,5]$. Leachate is defined as the aqueous effluent generated as a consequence of rainwater percolation through wastes, biochemical processes in waste's cells, and the inherent water content of wastes themselves [6]. When water percolates through solid wastes, both biological materials and chemical constituents are leached into solution $[7,8]$. The major concern with the movement of leachate into the subsurface aquifer is the fate of the constituents found in waste [9].

In landfill, technical and geological barrier systems are employed to minimize uncontrolled emissions from the waste into the environment. The barrier systems contain a liner material, which should have a low hydraulic conductivity and the ability to attenuate pollutants migrating through the barrier [10]. Liner materials must be developed or improved with respect to ecological and economical requirements. Moreover, these materials to prevent or control shrinkage and/or desiccation cracking need to be further investigated (the choice of suitable liner material, modifications affecting leachate quality, etc.).

Bentonite, which is typically clay, is widely used for liner material in the barrier system. It has local availability and a low hydraulic conductivity. However, leakage can result from shrinkage cracking if only bentonite is used [11]. For this reason, a suitable sand-bentonite mixture to determine 
the minimum percentage of bentonite necessary to fulfil the given requirements is the main task [12]. Previous studies showed that quantities higher than $15 \%$ of bentonite as an amendment in a mixture do not lead to a significant decrease in hydraulic conductivity, while strength properties and mechanical behaviour of the mixture may be adversely affected by the clay $[13,14]$.

The artificial neural network (ANN) is a system of data processing based on the structure of a biological neural system. The prediction with ANN is made by learning of the experimentally generated data or using validated models [15]. Because of their reliable, robust, and salient characteristics in capturing the nonlinear relationships existing between variables (multiinput/output) in complex systems, numerous applications of ANN have been successfully conducted to solve environmental problems [16-18].

In the literature, there are few studies relating to operation problems for landfilling processes based on ANNs. In the present work, heavy metal removal during landfilling of industrial waste is investigated. The effects of various liner materials, such as bentonite, natural zeolite, expanded vermiculite, and pumice on the removal of $\mathrm{Cu}$ (II) and $\mathrm{Zn}$ (II) are examined. On the basis of batch adsorption experiments, a three-layer ANN model to predict heavy metal removal efficiency of composite used as a liner material is applied in this work. Removal of heavy metal from landfilling process is optimized to determine the optimal network structure. Finally, outputs obtained from the models are compared with the experimental data, and advantages and the further developments are also discussed.

\section{Material and Methods}

2.1. Materials. The three natural materials and the commercially available bentonite were investigated as a liner material in this study. Among them, natural zeolitee was obtained from the Rota Mining Industry (Gördes, Manisa, Turkey); expandable vermiculite was obtained from the Fitar Agricultural Industry (Antalya, Turkey); pumice was obtained from the Soylu Mining Industry (Nevşehir, Turkey); illite was obtained from Sud Chemie Mining Industry and Trade Co. Ltd. (Ordu, Turkey); kaolinite was obtained from the Kale Mining Industry and Trade Co. Ltd. (Çanakkale, Turkey); and bentonite was obtained from the Bensan Activated Bentonite Company (Enez, Edirne, Turkey). The chemical composition of the materials is presented in Table 1. Samples were crushed and then milled resulting in small particles with a size of about $0.5 \mathrm{~mm}$.

2.2. Experimental Procedure. The industrial waste obtained from an electroplating industry in Samsun (Turkey) was used in the experiments. Ten simulated landfill systems were used for the removal of heavy metal from leachate. The systems were composed with a capacity of $25 \mathrm{~L}(20 \mathrm{~cm} \times 25 \mathrm{~cm} \times$ $50 \mathrm{~cm}$ ).

Natural material-bentonite mixtures were prepared to evaluate how much these clays reduce the removal of heavy metal as liner materials. The amounts of natural materials used in the mixtures were $25 \%, 50 \%$, and $75 \%$ of mixtures as
TABLE 1: Chemical compositions of the liner materials.

\begin{tabular}{lcccc}
\hline Components & $\mathrm{B}$ & $\mathrm{NZ}$ & $\mathrm{EV}$ & $\mathrm{P}$ \\
\hline $\mathrm{Na}_{2} \mathrm{O}$ & 1.80 & 0.40 & 0.05 & 3.65 \\
$\mathrm{MgO}$ & 4.00 & 1.40 & 17.75 & 0.03 \\
$\mathrm{Al}_{2} \mathrm{O}_{3}$ & 17.00 & 11.80 & 18.45 & 12.27 \\
$\mathrm{SiO}_{2}$ & 61.00 & 71.00 & 41.29 & 73.44 \\
$\mathrm{CaO}$ & 2.50 & 3.40 & 0.25 & 0.96 \\
$\mathrm{TiO}_{2}$ & - & 0.10 & 1.21 & 0.10 \\
$\mathrm{~K}_{2} \mathrm{O}$ & 0.50 & 2.40 & 7.21 & 4.37 \\
$\mathrm{Fe}_{2} \mathrm{O}_{3}$ & 3.00 & 1.70 & 6.51 & 1.2 \\
$\mathrm{MnO}$ & - & - & 0.04 & 0.06 \\
$\mathrm{SO}$ & - & 0.12 & - & 0.08 \\
$\mathrm{LOI}$ & 3.51 & 6.87 & 5.02 & 3.72 \\
$\mathrm{CEC}$ (meq/100) & 31.8 & 166.3 & 52.9 & 34.6 \\
\hline
\end{tabular}

B: bentonite, NZ: natural zeolite, EV: expanded vermiculite, P: pumice.

volumetric. The mixture of natural liner materials is placed at the base of the simulated landfill systems. Total volume of liner material was $5 \mathrm{~L}$ for all systems. The system containing $100 \%$ of bentonite as a liner material was compared to other systems. A $20 \mathrm{~L}$ of industrial waste was deposited on the liner materials.

Leachate was collected from a drainage channel at the bottom of the system by adding distilled water. For each week, a total volume of $1 \mathrm{~L}$ influent was passed through the industrial waste sample. $500 \mathrm{~mL}$ of effluent was collected and acidified with concentrated nitric acid. The tests were conducted for 15 weeks. For each sample, the effluent was then analyzed for the heavy metal ions $\mathrm{Cu}^{2+}$ and $\mathrm{Zn}^{2+}$ using an atomic adsorption spectrophotometer (UNICAM 929 Model). Duplicate samples were prepared for all tests.

2.3. Artificial Neural Network Application. An effective way to modeling batch adsorption system for $\mathrm{Cu}$ (II) and $\mathrm{Zn}$ (II) removal is achieved by the use of artificial neural network (ANN). Nowadays, considerable achievements in artificial intelligence techniques can be used to model and predict the responses in complex systems. These techniques can enhance the predicting ability of the model such as adsorption systems if the mathematical or statistical methods fail to formulate with the desired accuracy.

A lot of scientists present ANN techniques for modeling batch experimental systems. Generally, feed-forward back propagation (FFBP) ANNs were successfully used in adsorption studies [19-24]. Details about ANNs can be found in the related literature. All these techniques use more or less the same network architecture. The optimum network type is found by trial and error, and training procedures for these suggested ANNs need long computer runs. FFBP consists of one input layer, one or several hidden layers, and one output layer. Back propagation (BP) learning algorithm is usually used for learning procedure. The mathematical background of BP algorithm can be found in $[25,26]$.

In this paper a simple ANN topology with 2 neurons in input layer, 2 neurons in hidden layer, and 2 neurons in output layer is needed to model the system. There are a number 


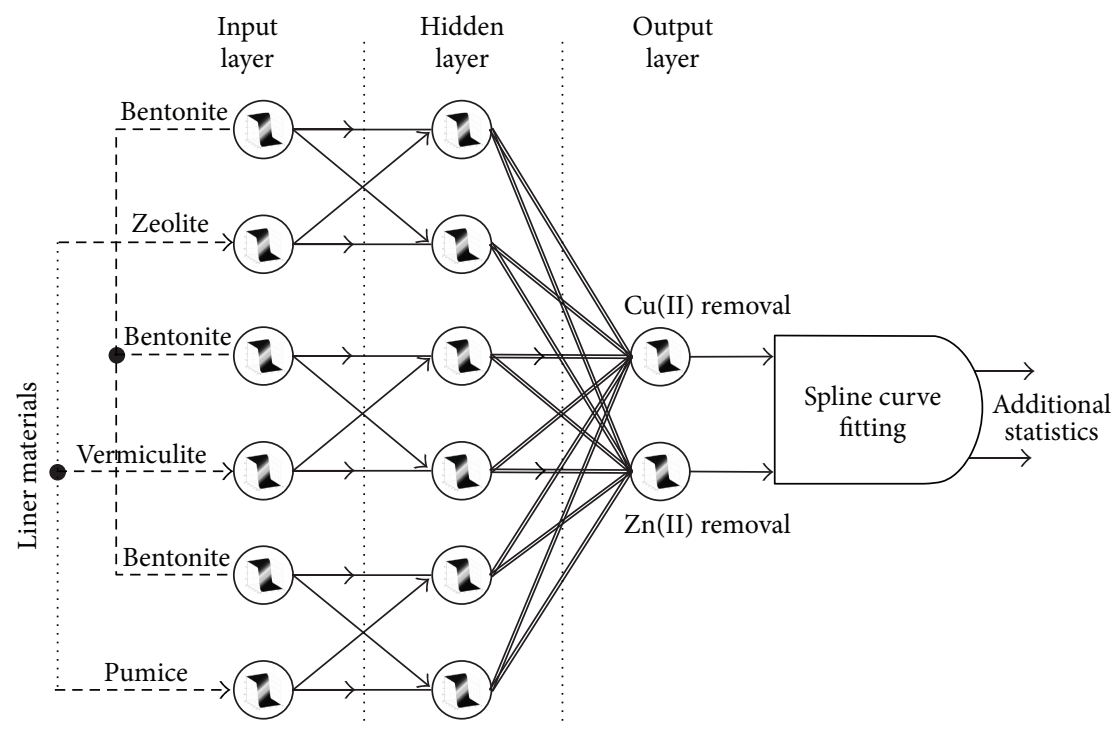

FIGURE 1: Proposed ANN structure for modeling adsorption system.

TABLE 2: The whole experimental system.

\begin{tabular}{lcc}
\hline Liner materials $\%$ & $\mathrm{Cu}(\mathrm{II})$ removal (\%) & Zn(II) removal (\%) \\
\hline Bentonite & 45.07 & 48.19 \\
$25 \%$ natural zeolite $+75 \%$ bentonite & 63.27 & 60.47 \\
$50 \%$ natural zeolite $+50 \%$ bentonite & 89.20 & 80.90 \\
$75 \%$ natural zeolite $+25 \%$ bentonite & 98.34 & 95.29 \\
$25 \%$ vermiculite $+75 \%$ bentonite & 47.97 & 50.31 \\
$50 \%$ vermiculite $+50 \%$ bentonite & 52.73 & 68.98 \\
$75 \%$ vermiculite $+25 \%$ bentonite & 77.41 & 81.49 \\
$25 \%$ pumice $+75 \%$ bentonite & 52.38 & 50.00 \\
$50 \%$ pumice $+50 \%$ bentonite & 57.50 & 67.50 \\
$75 \%$ pumice $+25 \%$ bentonite & 78.62 & 74.24 \\
\hline
\end{tabular}

of common activation functions in use with ANNs. The most common choice of activation functions for multilayered perceptron (MLP) is used as hyperbolic tangent function (Figure 1).

As seen in Figure 1 three liner materials were tested to see the efficiency of the proposed batch experimental system to maximize the $\mathrm{Cu}(\mathrm{II})$ and $\mathrm{Zn}(\mathrm{II})$ removal. Training process consists of four steps: (a) assemble the training data, (b) decide the network type, (c) train the network, and (d) calculate the output for test data. Unlike experimental design, the proposed ANN uses only 2 inputs and responses of 2, that is, $\mathrm{Cu}(\mathrm{II})$ and $\mathrm{Zn}(\mathrm{II})$ removal. Therefore, it is easy to implement and cost-effective.

The input and target data were selected from Table 2. The percentage of each liner material, that is, natural zeolite, expanded vermiculite, and pumice, and removal efficiencies were used for training procedures.

Table 2 actually was used for training the ANNs according to the network parameters given in Table 3.

For testing the ANNs (Figure 1) the ratio of each liner with respect to bentonite was changed from 5\% to $95 \%$ and the outputs of ANNs were predicted. This testing procedure
TABLE 3: Training parameters for all ANNs.

\begin{tabular}{lc}
\hline Max. iteration & 20000 \\
\hline Learn rate start control iteration & 1.000 \\
Learn rate & 0.075 \\
Min. learn rate & 0.001 \\
Max. learn rate & 0.075 \\
Momentum & 0.800 \\
Tolerance & 0.000 \\
RMS error & 0.000 \\
\hline
\end{tabular}

yielded to 19 trials. Three of the total trials such as $25 \%, 50 \%$, and $75 \%$ of the liner materials and $75 \%, 50 \%$, and $25 \%$ of bentonite were already used in testing process and these three trials were then used to check the consistency of the ANNs. Figures 2 and 3 demonstrate the performance of the suggested ANNs topology for $\mathrm{Cu}(\mathrm{II})$ and $\mathrm{Zn}$ (II) removal, respectively.

In Figures 2 and 3 line 1 demonstrates the optimal point for natural zeolite material while line shows the optimal points for the materials of expanded vermiculite and pumice. 
TABLE 4: Basic statistics for interpolated ANN outputs.

\begin{tabular}{|c|c|c|c|c|c|c|}
\hline Descriptive statistics & $\mathrm{Cu}(\mathrm{II})_{\text {natural zeolite }}$ & $\mathrm{Cu}(\mathrm{II})_{\text {vermiculite }}$ & $\mathrm{Cu}(\mathrm{II})_{\text {pumice }}$ & $\mathrm{Zn}(\mathrm{II})_{\text {natural zeolite }}$ & $\mathrm{Zn}(\mathrm{II})_{\text {vermiculite }}$ & $\mathrm{Zn}(\mathrm{II})_{\text {pumice }}$ \\
\hline Minimum & 58.83 & 47.37 & 51.63 & 57.06 & 46.57 & 46.57 \\
\hline Maximum & 99.93 & 82.05 & 82.77 & 98.15 & 83.89 & 75.52 \\
\hline Mean & 82.74 & 60.60 & 63.86 & 78.69 & 66.68 & 63.38 \\
\hline Median & 89.20 & 52.73 & 57.50 & 80.90 & 68.98 & 67.50 \\
\hline Mod & 58.83 & 47.37 & 51.63 & 57.06 & 46.97 & 46.97 \\
\hline Standard value & 16.62 & 14.35 & 12.74 & 16.38 & 14.64 & 11.46 \\
\hline Range & 41.10 & 34.68 & 31.13 & 41.09 & 36.93 & 28.55 \\
\hline
\end{tabular}

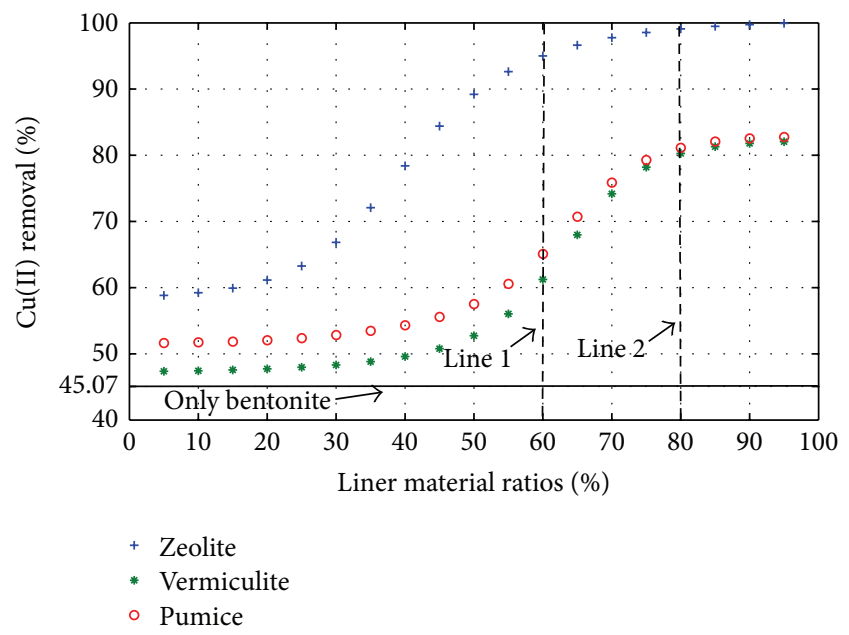

FIGURE 2: Prediction of $\mathrm{Cu}(\mathrm{II})$ removal with different liner materials.

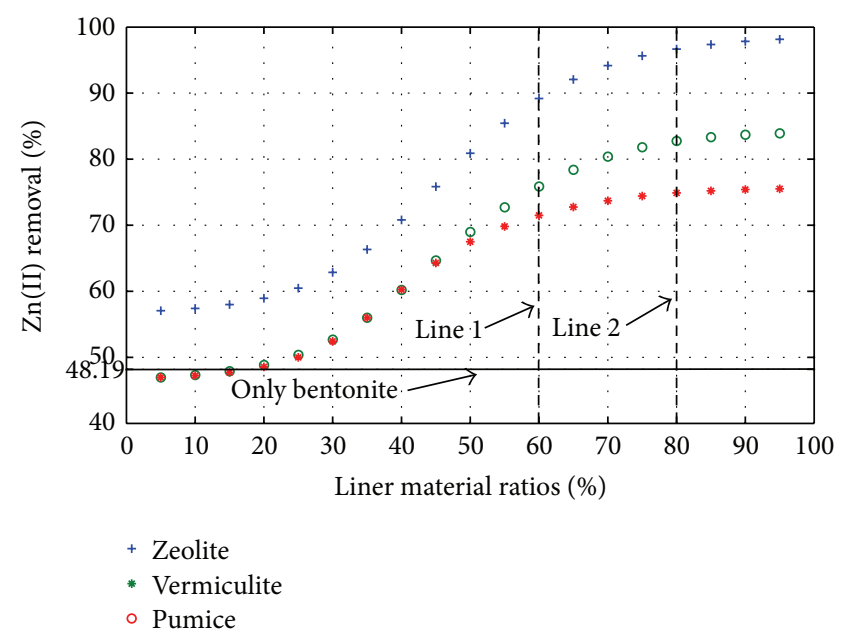

FIgURE 3: Prediction of $\mathrm{Zn}(\mathrm{II})$ removal with different liner materials.

Consequently, $60 \%$ of natural zeolite with $40 \%$ of bentonite combination was found to be best for $\mathrm{Cu}(\mathrm{II})$ removal $(95 \%)$ and $80 \%$ of expanded vermiculite and pumice with $20 \%$ of bentonite combination was found to be the best for $\mathrm{Zn}$ (II) removal (61.24\% and $65.09 \%)$. Similarly, $60 \%$ of natural zeolite with $40 \%$ of bentonite combination was found to be the best for $\mathrm{Zn}$ (II) removal (89.19\%), and $80 \%$ of expanded vermiculite and pumice with $20 \%$ of bentonite combination was found to be the best for $\mathrm{Zn}$ (II) removal $(82.76 \%$ and $74.89 \%)$. A minimum liner material and bentonite combination can be selected as $20 \%$ according to Figures 2 and 3 since there is no significant change in the removal efficiency up to that point.

The intermediate values of the outputs of ANNs can also be tested by cubic spline interpolation technique. Equation (1) gives the mathematical explanation of the interpolation technique:

$$
S(z, v, p)=\left\{\begin{array}{l}
a x^{3}+b x^{2}+c x+d \\
e x^{3}+f x^{2}+g x+h
\end{array}\right.
$$

In (1) $z, v$, and $p$ stand for natural zeolite, expanded vermiculite, and pumice, respectively, and $x$ represents the interval areas, that is, from 5\% to $95 \%$. Table 4 gives the descriptive statistics of the interpolated outputs of ANNs.

The removal efficiencies were calculated as $45.07 \%$ and $48.19 \%$ for $\mathrm{Cu}$ (II) and $\mathrm{Zn}$ (II), respectively (Table 1), when only bentonite was used as liner material. However, the use of other liner materials in specific ratios had significant effect on removal efficiencies (Table 3 ).

\section{Conclusion}

The idea of the study was to examine the feasibility of using different liner materials to remove $\mathrm{Cu}$ (II) and $\mathrm{Zn}$ (II) from industrial leachate. The following outcomes can be derived from this ongoing research work.

(a) The traditional use of bentonite as a liner material has low removal efficiency comparing to combinations of natural zeolite + bentonite, expanded vermiculite + bentonite, and pumice + bentonite mixtures.

(b) The suggested ANN topology was found effective to model the experimental design.

(c) Applying cubic spline curve fitting of the removal efficiencies enables the provision of additional descriptive statistics.

(d) Among the different combinations of liner materials $60 \%$ of natural zeolite $+40 \%$ of bentonite was found the optimum with high removal efficiencies of $95 \%$ for $\mathrm{Cu}(\mathrm{II})$ and $89.19 \%$ for $\mathrm{Zn}(\mathrm{II})$. 


\section{References}

[1] M. Alkan, B. Kalay, M. Doǧan, and Ö. Demirbaş, "Removal of copper ions from aqueous solutions by kaolinite and batch design," Journal of Hazardous Materials, vol. 153, no. 1-2, pp. 867-876, 2008.

[2] F. Claret, C. Tournassat, C. Crouzet et al., "Metal speciation in landfill leachates with a focus on the influence of organic matter," Waste Management, vol. 31, no. 9-10, pp. 2036-2045, 2011.

[3] T. Aman, A. A. Kazi, M. U. Sabri, and Q. Bano, "Potato peels as solid waste for the removal of heavy metal copper(II) from waste water/industrial effluent," Colloids and Surfaces B, vol. 63, no. 1, pp. 116-121, 2008.

[4] P. H. Brunner and J. Fellner, "Setting priorities for waste management strategies in developing countries," Waste Management and Research, vol. 25, no. 3, pp. 234-240, 2007.

[5] D. Laner, M. Crest, H. Scharff, J. W. F. Morris, and M. A. Barlaz, "A review of approaches for the long-term management of municipal solid waste landfills," Waste Management, vol. 32, no. 3, pp. 498-512, 2012.

[6] S. Renou, J. G. Givaudan, S. Poulain, F. Dirassouyan, and P. Moulin, "Landfill leachate treatment: review and opportunity," Journal of Hazardous Materials, vol. 150, no. 3, pp. 468-493, 2008.

[7] T. Chalermyanont, S. Arrykul, and N. Charoenthaisong, "Potential use of lateritic and marine clay soils as landfill liners to retain heavy metals," Waste Management, vol. 29, no. 1, pp. 117127, 2009.

[8] G. di Bella, D. di Trapani, G. Mannina, and G. Viviani, "Modeling of perched leachate zone formation in municipal solid waste landfills," Waste Management, vol. 32, no. 3, pp. 456-462, 2012.

[9] N. Yusof, A. Haraguchi, M. A. Hassan, M. R. Othman, M. Wakisaka, and Y. Shirai, "Measuring organic carbon, nutrients and heavy metals in rivers receiving leachate from controlled and uncontrolled municipal solid waste (MSW) landfills," Waste Management, vol. 29, no. 10, pp. 2666-2680, 2009.

[10] K. Czurda, "Encapsulation parameters in waste deposit technology: geologic barriers and liner systems," Geo.Alp, vol. 3, pp. 207-214, 2006.

[11] L. H. Mollins, D. I. Stewart, and T. W. Cousens, "Predicting the properties of bentonite-sand mixtures," Clay Minerals, vol. 31, no. 2, pp. 243-252, 1996.

[12] T. B. Musso, K. E. Roehl, G. Pettinari, and J. M. Vallés, "Assessment of smectite-rich claystones from Northpatagonia for their use as liner materials in landfills," Applied Clay Science, vol. 48, no. 3, pp. 438-445, 2010.

[13] T. C. Kenney, W. A. van Veen, M. A. Swallow, and M. A. Sungaila, "Hydraulic conductivity of compacted bentonite-sand mixtures," Canadian Geotechnical Journal, vol. 29, no. 3, pp. 364-374, 1992.

[14] T. Abichou, C. H. Benson, and T. B. Edil, "Micro-structure and hydraulic conductivity of simulated sand-bentonite mixtures," Clays and Clay Minerals, vol. 50, no. 5, pp. 537-545, 2002.

[15] M. R. Fagundes-Klen, L. G. L. Vaz, M. T. Veit, C. E. Borba, E. A. Silva, and A. D. Kroumov, "Biosorption of the copper and cadmium ions-a study through adsorption isotherm analysis," Bioautomation, vol. 7, no. 1, pp. 23-33, 2007.

[16] D. Salari, N. Daneshvar, F. Aghazadeh, and A. R. Khataee, "Application of artificial neural networks for modeling of the treatment of wastewater contaminated with methyl tert-butyl ether (MTBE) by $\mathrm{UV} / \mathrm{H}_{2} \mathrm{O}_{2}$ process," Journal of Hazardous Materials, vol. 125, no. 1-3, pp. 205-210, 2005.

[17] K. Yetilmezsoy and S. Demirel, "Artificial neural network (ANN) approach for modeling of $\mathrm{Pb}$ (II) adsorption from aqueous solution by Antep pistachio (Pistacia Vera L.) shells," Journal of Hazardous Materials, vol. 153, no. 3, pp. 1288-1300, 2008.

[18] S. Aber, A. R. Amani-Ghadim, and V. Mirzajani, "Removal of $\mathrm{Cr}(\mathrm{VI})$ from polluted solutions by electrocoagulation: modeling of experimental results using artificial neural network," Journal of Hazardous Materials, vol. 171, no. 1-3, pp. 484-490, 2009.

[19] N. G. Turan, B. Mesci, and O. Ozgonenel, "The use of artificial neural networks (ANN) for modeling of adsorption of $\mathrm{Cu}$ (II) from industrial leachate by pumice," Chemical Engineering Journal, vol. 171, no. 3, pp. 1091-1097, 2011.

[20] D.-J. Choi and H. Park, "A hybrid artificial neural network as a software sensor for optimal control of a wastewater treatment process," Water Research, vol. 35, no. 16, pp. 3959-3967, 2001.

[21] Ö. Çinar, H. Hasar, and C. Kinaci, "Modeling of submerged membrane bioreactor treating cheese whey wastewater by artificial neural network," Journal of Biotechnology, vol. 123, no. 2, pp. 204-209, 2006.

[22] A. Wang, C. Liu, H. Han, N. Ren, and D.-J. Lee, "Modeling denitrifying sulfide removal process using artificial neural networks," Journal of Hazardous Materials, vol. 168, no. 2-3, pp. 1274-1279, 2009.

[23] R. M. Aghav, S. Kumar, and S. N. Mukherjee, "Artificial neural network modeling in competitive adsorption of phenol and resorcinol from water environment using some carbonaceous adsorbents," Journal of Hazardous Materials, vol. 188, no. 1-3, pp. 67-77, 2011.

[24] D. Saha, A. Bhowal, and S. Datta, "Artificial neural network modeling of fixed bed biosorption using radial basis approach," Heat and Mass Transfer, vol. 46, no. 4, pp. 431-436, 2010.

[25] R. A. Chayjan and M. Esna-Ashari, "Comparison between artificial neural networks and mathematical models for estimating equilibrium moisture content in raisin," Agricultural Engineering International: The CIGRE Journal, vol. 12, no. 1, p. 158, 2010.

[26] R. Singh, R. S. Bhoopal, and S. Kumar, "Prediction of effective thermal conductivity of moist porous materials using artificial neural network approach," Building and Environment, vol. 46, no. 12, pp. 2603-2608, 2011. 

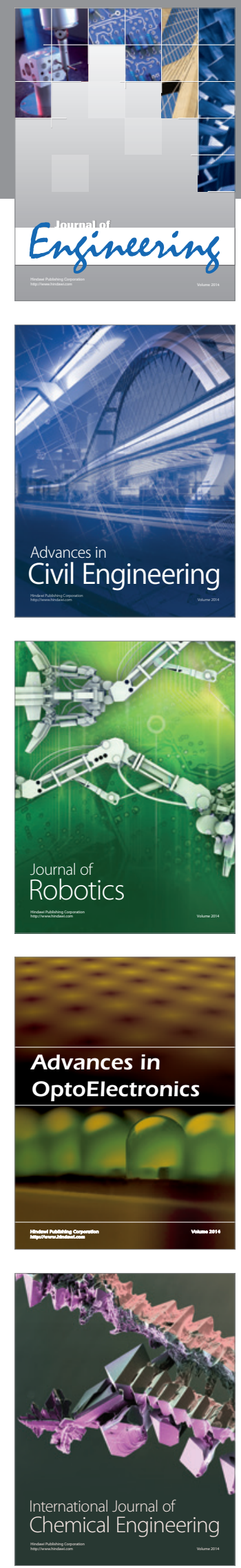

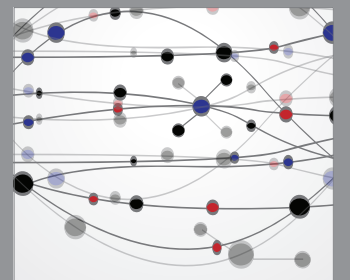

The Scientific World Journal
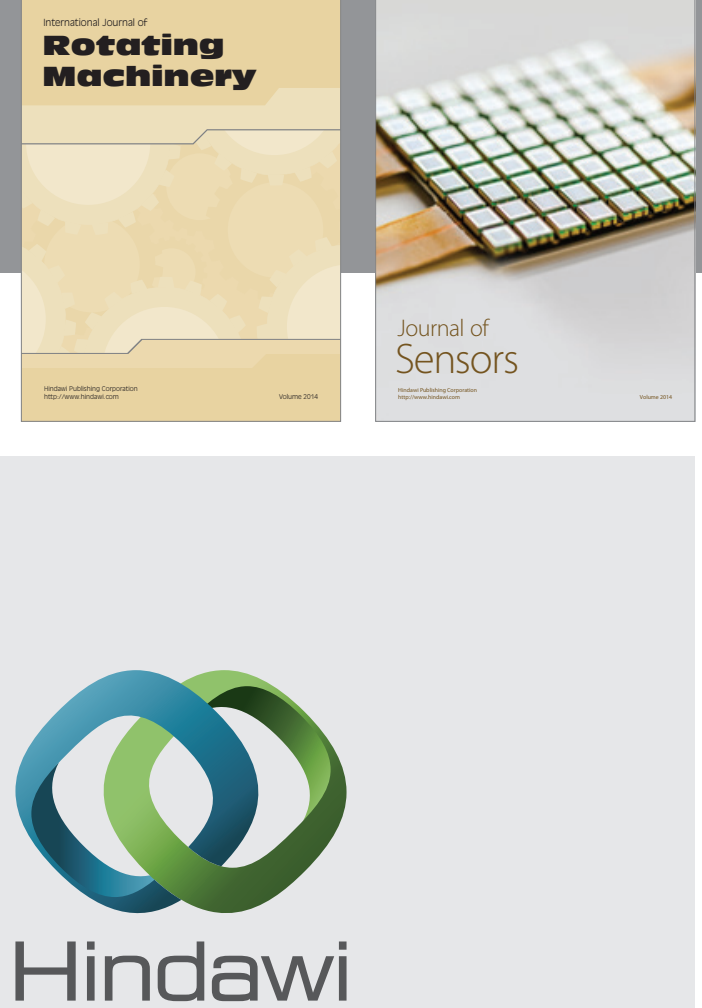

Submit your manuscripts at http://www.hindawi.com
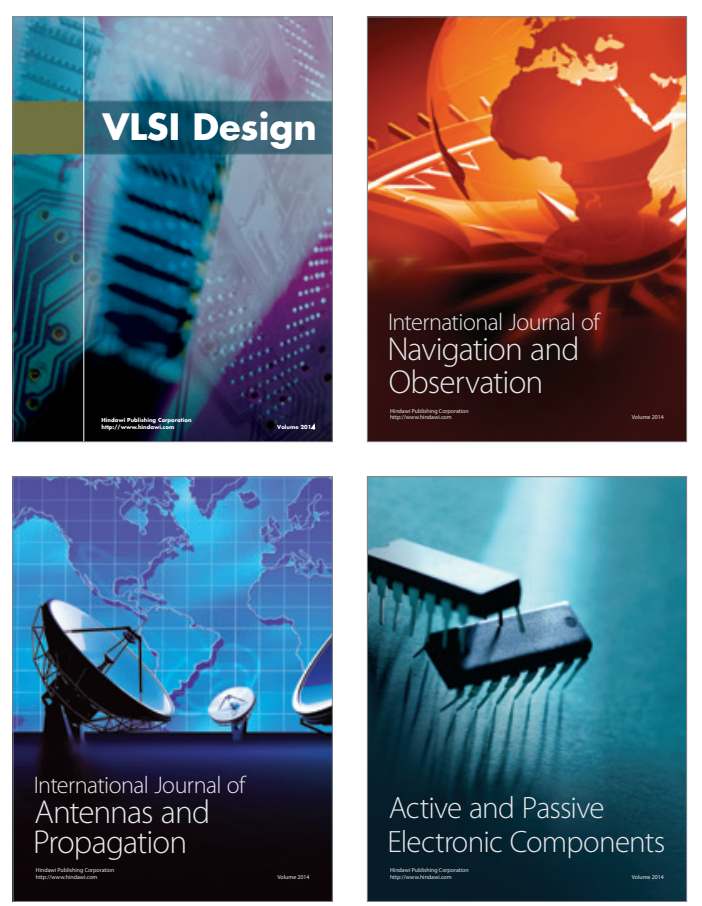
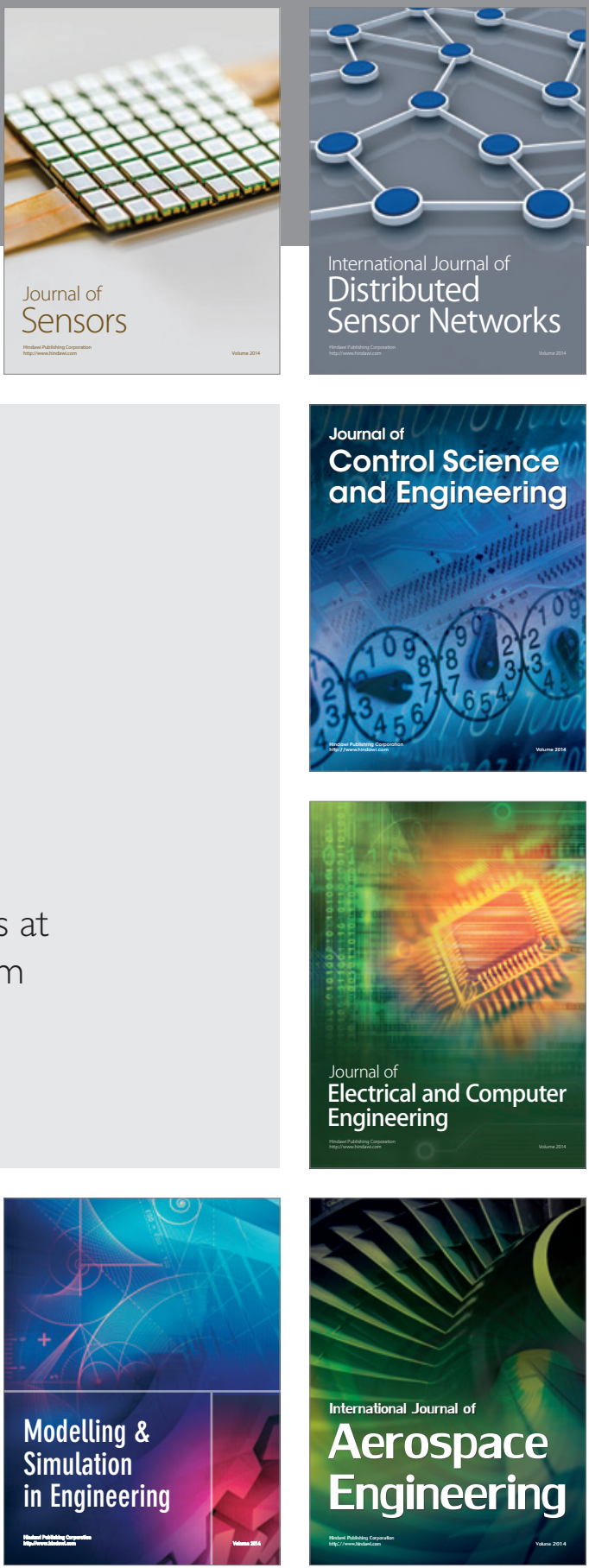

Journal of

Control Science

and Engineering
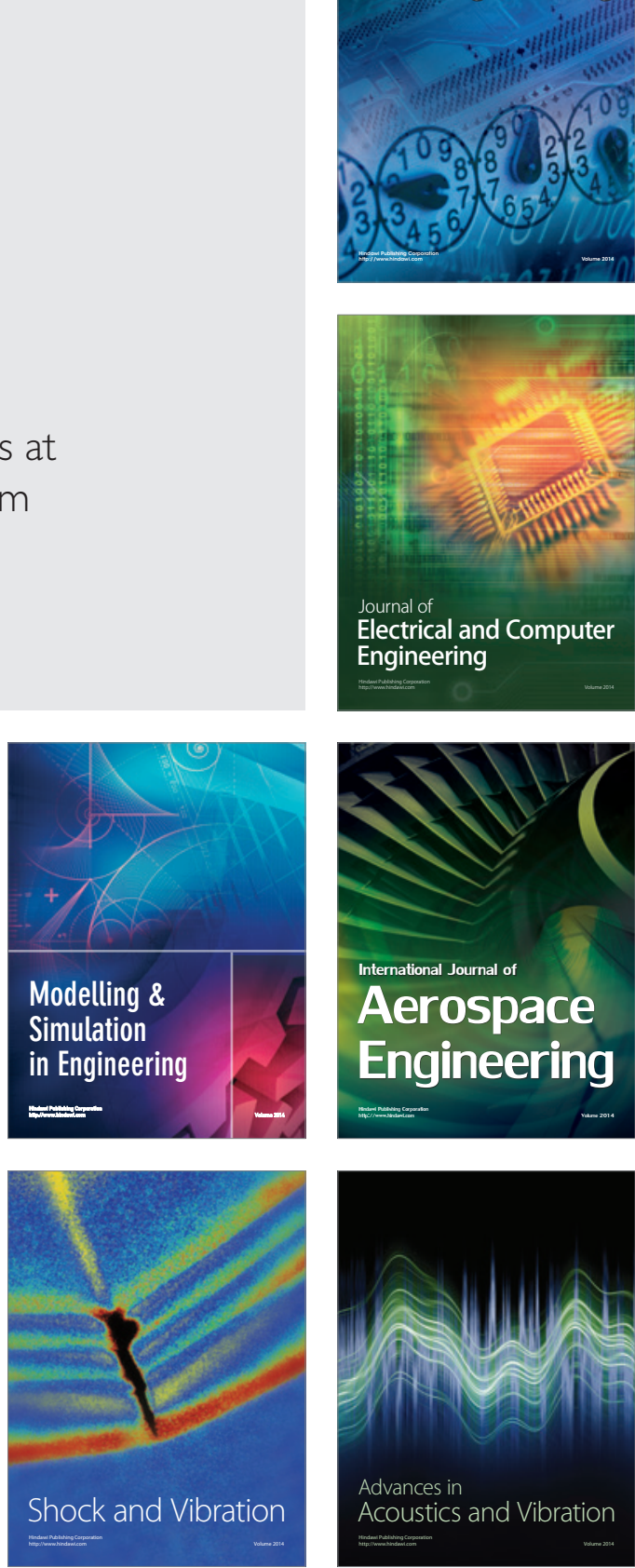